\title{
Microbial Symbiosis in Mosquito Vectors ${ }^{\dagger}$
}

\section{Guido Favia}

Citation: Favia, G. Microbial Symbiosis in Mosquito Vectors, in Proceedings of the 1st International Electronic Conference on Entomology, 1-15 July 2021, MDPI: Basel, Switzerland, doi:10.3390/IECE-10641

Published: 8 July 2021

Publisher's Note: MDPI stays neutral with regard to jurisdictional claims in published maps and institutional affiliations.

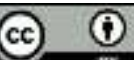

Copyright: (c) 2021 by the authors. Submitted for possible open access publication under the terms and conditions of the Creative Commons Attribution (CC BY) license (http://creativecommons.org/licenses /by/4.0/).
University of Camerino, 62032 Camerino (MC), Italy

Correspondence: guido.favia@unicam.it

+ Presented at the 1st International Electronic Conference on Entomology (IECE 2021), 1-15 July 2021; Available online: https://iece.sciforum.net/.

\begin{abstract}
Mosquitoes host diverse bacterial communities influenced by the sex of the mosquito, tissue, and developmental stages, among other factors. Consequently, the mosquito microbiota may impact on several aspects of the host biology, including nutrition, development and reproduction. We have recently revealed a shared core microbiota among different mosquito species, although interesting inter- and intra-species differences were detected. Additionally, we showed deep divergences between genera, underlining microbiota specificity and adaptation to their host suggesting that the holobiont of different mosquito species may significantly vary. Moreover, mosquito species are characterized by distinctive microbiota in different organs, likely reflecting different functions and/or adaptation processes. Understanding of the microbiota of mosquitoes in relation to sex, developmental stage and tissue, may ultimately provide crucial insights and novel targets for possible application of symbionts in innovative strategies for the control of vector borne diseases, globally named Symbiotic Control (SC). Here I report some advances in the study of microbial symbiosis in mosquitoes with particular reference to the acetic bacterium Asaia, the best characterized Anopheline symbiont, for which some conditioning on the biology of the host are proposed, including, for example, a possible impact on insecticide-resistance mechanism sdeveloped by mosquitoes.
\end{abstract}

Keywords: Symbiosis; Mosquito Vectors; Asaia 